\title{
Geo-Epidemiological Study of Leptospira spp. Infection in Cattle, Feral Cats and Rodents of the Fernando de Noronha Island, Brazil
}

\author{
Eduardo Guelfer Ferrer de Morais', Fernando Jorge Rodrigues Magalhães', \\ Carlos Diógenes Ferreira de Lima Filho' ${ }^{2}$, Daniel Friguglietti Brandespim?', \\ Pollyane Raysa Fernandes de Oliveira', Diego Figueiredo da Costa ${ }^{3}$, \\ Sérgio Santos de Azevedo ${ }^{3}$ \& Rinaldo Aparecido Mota'
}

\begin{abstract}
Background: Leptospirosis is a re-emergent contagious infectious disease, caused by pathogenic leptospires that are transmitted by the urine of infected animals or bacteria-contaminated water and mud. In tropical and subtropical countries it presents high prevalence due to the temperature and humidity conditions that favor the maintenance of the agent in the environment. This disease can affect several species, in Brazilian cattle is an endemic disease, and studies have shown a high occurrence of Leptospira spp. infection in beef and dairy herds. Domestic cats as well as other species of the Family Felidae seem to be resistant to leptospirosis. However, it has been demonstrated under experimental conditions that cats may become infected by ingestion of infected rodents and contaminated water. The present study investigated the occurrence of Leptospira spp. infection in cattle, feral cats and rodents of the Fernando de Noronha Island.

Materials, Methods \& Results: Fernando de Noronha Island is located $360 \mathrm{~km}$ far from Recife and Natal, capitals of the states of Pernambuco and Rio Grande do Norte, Brazil, respectively. It has an area of approximately $18.4 \mathrm{~km}^{2}$ and constitutes the submerged part of a volcanic edifice currently inactive, which base rests 4,000 m deep in the Atlantic Ocean. Blood samples were collected from all the cattle raised in the Island $(n=88), 200$ feral cats and 150 rodents, and the sera were screened by MAT (Serogroups: Australis; Autumnalis; Ballum; Bataviae; Canicola; Cynopteri; Djasiman; Grippotyphosa; Hebdomadis; Icterohaemorrhagiae; Icterohaemorrhagiae; Panama; Pomona; Pyrogenes; Sejroe e Tarassovi) for detection of anti-Leptospira spp. antibodies. Initially all sera were screened at 1:100 dilution and those with $50 \%$ or more agglutination were titrated at two-fold geometric dilutions. The serum titer was defined as the reciprocal of the highest positive dilution. The plane coordinates obtained by Global Position System (GPS) were used for developing a spatial map of the Fernando de Noronha Island. The geo-referenced data were plotted in the ArcGIS 10.1 software. Approximately 22\% (20/88) and $12 \%(19 / 150)$ of the cattle and rodents were serologically reactive against Leptospira spp. antigens, respectively. The antibody titers of cattle ranged from 100 to 800 as shown. All the rodents screened were reactive against only one serovar and their antibody titers ranged from 100 to 3200. None of the serum samples from cats was reactive against the serovars tested. The serogroup Icterohaemorrhagiae predominated among the seropositive cattle, being found in $100 \%$ of the reactive samples. In rodents, the serogroups Icterohaemorrhagiae, Djasiman and Australis were responsible for 73.7\% (14/19), $21.0 \%(4 / 19)$ and $5.2 \%(1 / 19)$ of the infections, respectively.

Discussion: We believe that rodents and cattle play an important role in the dissemination of this disease, thus, it is necessary adopting prophylactic measures aimed at leptospirosis in the study area, in view of the human cases of leptospirosis reported and confirmed in the Island. These results are unprecedented in an insular environment in Brazil. Strategies aimed at better sanitary management of the cattle herds as well as population control of rodents must be implemented in the Fernando de Noronha Island to secure a more sustainable animal production and minimize the risks to public health.
\end{abstract}

Keywords: leptospirosis, microscopic agglutination test, zoonosis.

DOI: $10.22456 / 1679-9216.79176 .88400$ 


\section{INTRODUCTION}

Leptospirosis is a zoonosis of worldwide importance that affects rural and urban populations, especially in tropical and subtropical countries. It is caused by pathogenic leptospires that are transmitted by the urine of infected animals or bacteria-contaminated water and mud [12,27,43]. This disease causes reproductive disorders in production animals decreasing their productivity. The most significant clinical symptoms in cattle are abortions, stillbirth and infertility [24]. Cattle infected with the serovars Grippotyphosa and Pomona usually present apparent clinical manifestations and acute symptoms. On the other hand, animals infected with the serovar Sejroe, especially the serotype Hardjo, develop a chronic and subclinical disease associated with reproductive disorders [42].

Domestic cats as well as other species of the Family Felidae seem to be resistant to leptospirosis [30]. However, it has been demonstrated under experimental conditions that cats may become infected by ingestion of infected rodents and contaminated water [38]. Synanthropic rodents of the species Rattus norvegicus, Rattus rattus and Mus musculus are the most important reservoirs of leptospires [7,37].

According to the Ministry of Health of Brazil, seven cases of human leptospirosis have been confirmed in the Fernando de Noronha Island. In 2005 and 2016, the infected patients died because of the disease [6]. In view of the above, the present study investigated the occurrence of Leptospira spp. infection in cattle, feral cats and rodents of the Fernando de Noronha Island, Brazil.

\section{MATERIALS AND METHODS}

\section{Study area}

The Fernando de Noronha Island is located between latitudes $3^{\circ} 45^{\prime} \mathrm{S}$ and $3^{\circ} 57^{\prime} \mathrm{S}$ and longitudes $32^{\circ} 19^{\prime} \mathrm{W}$ and $32^{\circ} 41^{\prime} \mathrm{W}$; $545 \mathrm{~km}$ and $360 \mathrm{~km}$ far from Recife and Natal, capitals of the states of Pernambuco and Rio Grande do Norte, Brazil, respectively. It has an area of approximately $18.4 \mathrm{~km}^{2}$ and constitutes the submerged part of a volcanic edifice currently inactive, which base rests 4,000 m deep in the Atlantic Ocean. Its climate is characterized by well-defined dry (August to March) and rainy (March to August) seasons [41].

The Fernando de Noronha Island is not selfsufficient in food production; thus, several primary food items are imported from the mainland. The main economic activity in the Island is tourism, which has supplanted subsistence fishing. Agricultural activities are limited to small crops of leafy green vegetables, corn, beans, manioc and sugar cane. In the sixties, the Fernando de Noronha Island served as a quarantine area for cattle, water buffaloes, goats and sheep that were imported from India by a farmer from the state of Paraná, Brazil. Currently, there are small ranches of cattle, goats, sheep, pigs and poultry [1]. Domestic dogs and cats as well as feral cats are also present in the island, and there are large populations of three species of synanthropic rodents, the house mouse (Mus musculus), the black rat (Rattus rattus) and the Norway rat (Rattus norvegicus).

\section{Cattle herd}

The total number of cattle in the Fernando de Noronha Island is 88 , which are distributed among 6 rural properties located in 6 different neighborhoods. The production systems are extensive or semi-intensive and there is only one dairy herd. None of the cattle herds has been vaccinated against leptospirosis and there are no records of zootechnical data, characterizing the rural properties as little technified.

\section{Blood samples}

Blood samples were collected from all 88 cattle of the Fernando de Noronha Island, 200 feral cats (Felis catus) and 150 rodents of both species, Rattus norvegicus and Rattus rattus. The cattle were restrained for blood collection and the blood samples $(10 \mathrm{~mL})$ were collected by either jugular or caudal venipuncture. The feral cats were trapped and anesthetized with ketamine hydrochloride ${ }^{1}$ (Quetamina ${ }^{\circledR} 10 \mathrm{~g}$ ) and xylazine hydrochloride ${ }^{2}$ (Xilazin ${ }^{\circledR} 2 \%$ ) intramuscularly and then $5 \mathrm{~mL}$ of blood were collected by cephalic venipuncture. The rodents were captured using live trap (Tomahawk traps baited with pineapple slices) distributed in several spots throughout the Island, and then anesthetized with ketamine hydrochloride ${ }^{1}(\mathrm{Qu}-$ etamina $^{\circledR} 10 \mathrm{~g}$ ) and xylazine hydrochloride ${ }^{2}\left(\right.$ Xilazin $^{\circledR}$ $2 \%$ ) intramuscularly. Subsequently, $3 \mathrm{~mL}$ of blood were withdrawn by cardiac venipuncture.

The blood samples were placed in isothermal boxes containing reusable ice packs and sent to the Animal Surveillance Unit of the Fernando de Noronha State District (Núcleo de Vigilância Animal do Distrito Estadual de Fernando de Noronha) where they were 
centrifuged at $1120 \mathrm{~g}$ for $10 \mathrm{~min}$. Subsequently, the sera were recovered into labeled Eppendorf ${ }^{\circledR}$ tubes and stored at $-20^{\circ} \mathrm{C}$ until further serological analysis.

\section{Serological analysis}

The serum samples were screened by the microscopic agglutination test (MAT) in the Laboratory of Transmissible Diseases (Laboratório de Doenças Transmissíveis), Federal University of Campina Grande (Universidade Federal de Campina Grande), Patos, state of Paraíba, Brazil, using a collection of 20 antigens, which serovars and serogroups are listed in Table 1.
Initially all sera were screened at 1:100 dilution and those with $50 \%$ or more agglutination were titrated at two-fold geometric dilutions. The serum titer was defined as the reciprocal of the highest positive dilution. Occurrence was calculated considering the number of animals reactive to one or more serovars. Serovars with the highest titers were determined as the predominant. Prior to the serological analyzes, the antigens were examined under a dark-field microscope to check motility, auto agglutination and contaminants. Positive and negative sera were included in all analysis.

Table 1. Species, serovars, serogroups and samples of Leptospira spp. used in the MAT.

\begin{tabular}{|c|c|c|c|}
\hline Species & Serovar & Serogroup & Sample \\
\hline L. interrogans & Bratislava & Australis & Jez-bratislava \\
\hline L. interrogans & Autumnalis & Autumnalis & Akiyami A \\
\hline L. borgpetersenii & Castellonis & Ballum & Castellon 3 \\
\hline L. interrogans & Bataviae & Bataviae & Van Tienen \\
\hline L. interrogans & Canicola & Canicola & Hond Utrecht \\
\hline L. kirschneri & Cynopteri & Cynopteri & $3522 \mathrm{C}$ \\
\hline L. interrogans & Djasiman & Djasiman & Djasiman \\
\hline L. kirschneri & Grippotyphosa & Grippotyphosa & Moskva V \\
\hline L. interrogans & Hebdomadis & Hebdomadis & Hebdomadis \\
\hline L. interrogans & Copenhageni & Icterohaemorrhagiae & Wijinberg \\
\hline L. interrogans & Icterohaemorrhagiae & Icterohaemorrhagiae & Verdun \\
\hline L. noguchii & Panama & Panama & CZ $214 \mathrm{~K}$ \\
\hline L. interrogans & Pomona & Pomona & Pomona \\
\hline L. interrogans & Pyrogenes & Pyrogenes & Salinem \\
\hline L. borgpetersenii & Sejroe & Sejroe & M 84 \\
\hline L. interrogans & Guaricura & Sejroe & Guaricura \\
\hline L. interrogans & Hardjobovis & Sejroe & Sponselee \\
\hline L. interrogans & Hardjoprajtino & Sejroe & OMS \\
\hline L. interrogans & Wolffi & Sejroe & 3705 \\
\hline L. borgpetersenii & Tarassovi & Tarassovi & Perepelitsin \\
\hline
\end{tabular}




\section{Spatial Distribution}

The plane coordinates obtained by Global Position System (GPS) were used for developing a spatial map of the Fernando de Noronha Island. The GPS was set to provide the plane coordinates in the Universal Transverse Mercator (UTM) projection in the South American Datum, 1969 (SAD-69), which corresponds to the coordinate system of the cartographic base of the Island. The geo-referenced data were plotted in the ArcGIS 10.1 software, using the Kernel intensity estimator, a non-parametric technique that enables filtration of the variability of a data set, retaining the essential characteristics of local data. Color gradient depicts the density of cases per property from low (green) to high (red).

\section{RESULTS}

Occurrence and spatial distribution of Leptospira spp. infection in cattle

The overall occurence of Leptospira spp. infection in cattle of the Fernando de Noronha Island was $22.7 \%$ (20/88) ranging from $16.6 \%$ to $60 \%$ in the different neighborhoods (Table 2).

Table 2. Prevalence of anti-Leptospira spp. antibodies in cattle of the Fernando de Noronha Island determined by MAT.

\begin{tabular}{cccccc}
\hline & & \multicolumn{2}{c}{ Positive } & \multicolumn{2}{c}{ Negative } \\
\cline { 3 - 6 } Neighborhoods & Samples (n) & AF & $\begin{array}{c}\text { RF } \\
(\%)\end{array}$ & AF & $\begin{array}{c}\text { RF } \\
(\%)\end{array}$ \\
\hline Floresta Nova & 4 & 2 & 50.0 & 2 & 50.0 \\
Floresta Velha & 20 & 4 & 20.0 & 16 & 80.0 \\
Três Paus & 24 & 4 & 16.6 & 20 & 83.3 \\
Boldró & 5 & 3 & 60.0 & 2 & 40.0 \\
Sueste & 11 & 2 & 18.2 & 9 & 81.8 \\
Estrada Velha do & 24 & 5 & 20.8 & 19 & 79.2 \\
Sueste & 88 & 20 & 22.7 & 68 & 77.3 \\
\hline Total & & & &
\end{tabular}

AF: Absolute Frequency; RF: relative Frequency.

The Kernel estimate for the number of reactive cattle in the Island is shown in Figure 1.

The serogroup Icterohaemorrhagiae was responsible for $100 \%$ of the infections detected in cattle. The serovars Copenhageni and Castellonis were identified as well, but with lower antibody titers than those of the serovar Icterohaemorrhagiae for the same sample. The antibody titers of cattle ranged from 100 to 800 as shown in Figure 2.
Occurrence and spatial distribution of Leptospira spp. infection in rodents

Of the 150 rodent evaluated, 19 (12.7\%) were reagent to different serovars of Leptospira spp. as shown in Table 3.

Table 3. Prevalence of anti-Leptospira spp. antibodies in rodents of the Fernando de Noronha Island determined by MAT.

\begin{tabular}{cccccc}
\hline \multirow{2}{*}{ Neighborhoods } & \multicolumn{2}{c}{ Samples (n) } & \multicolumn{2}{c}{ Positive } & \multicolumn{2}{c}{ Negative } \\
\cline { 2 - 6 } & tested & AF & $\begin{array}{c}\text { RF } \\
(\%)\end{array}$ & AF & RF (\%) \\
\hline Trinta 1 & 80 & 10 & 12.5 & 70 & 87.5 \\
Trinta 2 & 27 & 3 & 11.1 & 24 & 88.9 \\
Quixaba & 19 & 2 & 10.5 & 17 & 89.5 \\
Basinha & 14 & 2 & 14.3 & 12 & 85.7 \\
Vacaria & 10 & 2 & 20.0 & 8 & 80.0 \\
\hline Total & 150 & 19 & 12.7 & 131 & 87.3 \\
\hline AF: Absolute Frequency: RF: relative Frequency.
\end{tabular}

AF: Absolute Frequency; RF: relative Frequency.

The Kernel estimate for the number of rodents seropositive to Leptospira spp. in the Fernando de Noronha Island is shown in Figure 3.

The rodent samples had $73.7 \%, 21.0 \%$ and $5.2 \%$ seroreactivity to the serogroups Icterohaemorrhagiae, Djasman and Australis (serovars Icterohaemorrhagiae, Djasman and Bratislava), respectively. All the rodents screened were reactive against only one serovar and their antibody titers ranged from 100 to 3200 (Figure 4).

Occurrence of Leptospira spp. infection in cats

None of the 200 feral cats was reactive against any of the 20 Leptospira spp. serovars screened by MAT.

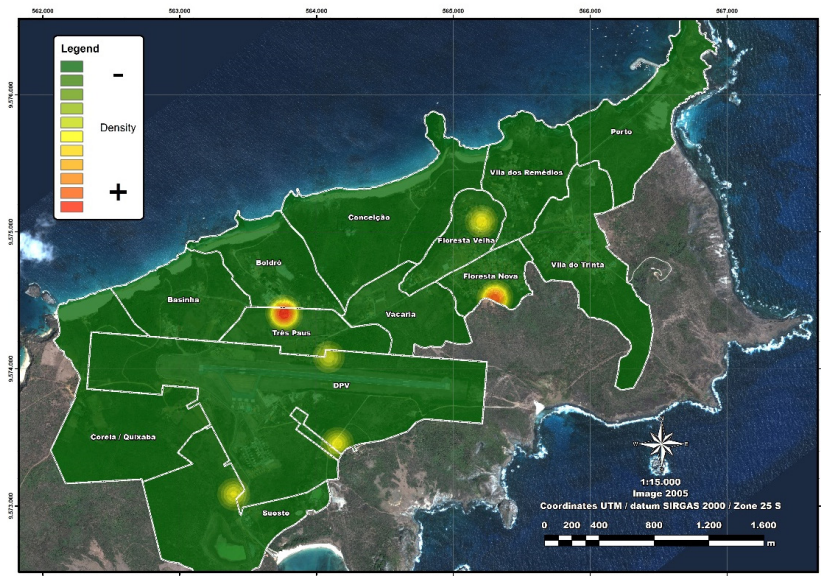

Figure 1. Kernel estimate for Leptospira spp. infection in cattle of the Fernando de Noronha Island, Pernambuco, Brazil. 


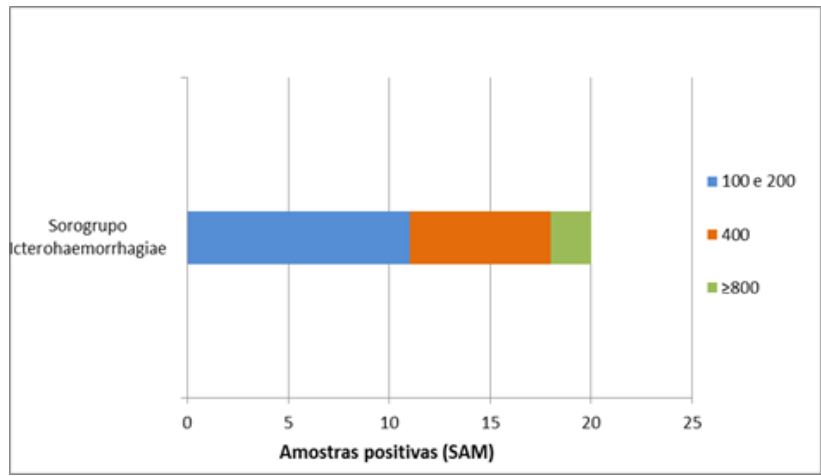

Figure 2. Titers of anti-Leptospira spp. antibodies in cattle of the Fernando de Noronha Island determined by MAT.

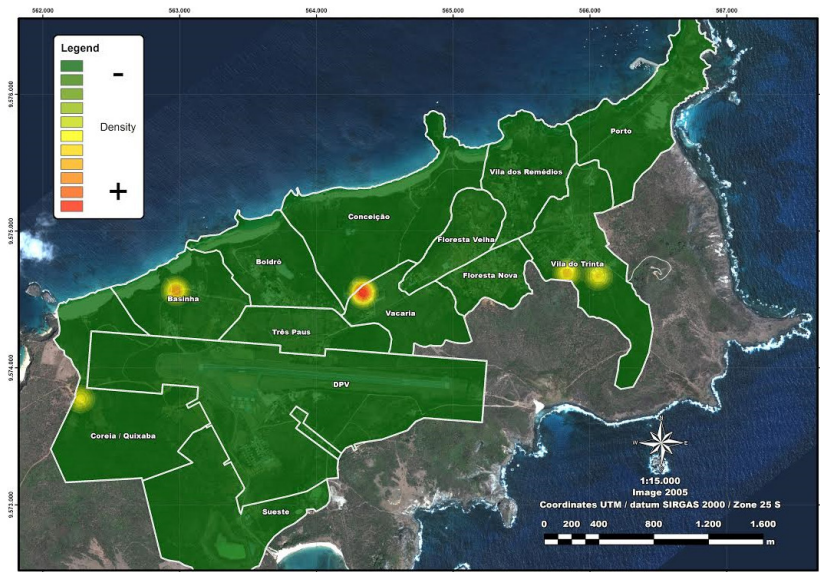

Figure 3. Kernel estimate for Leptospira spp. infection in rodents of the Fernando de Noronha Island, Pernambuco, Brazil.

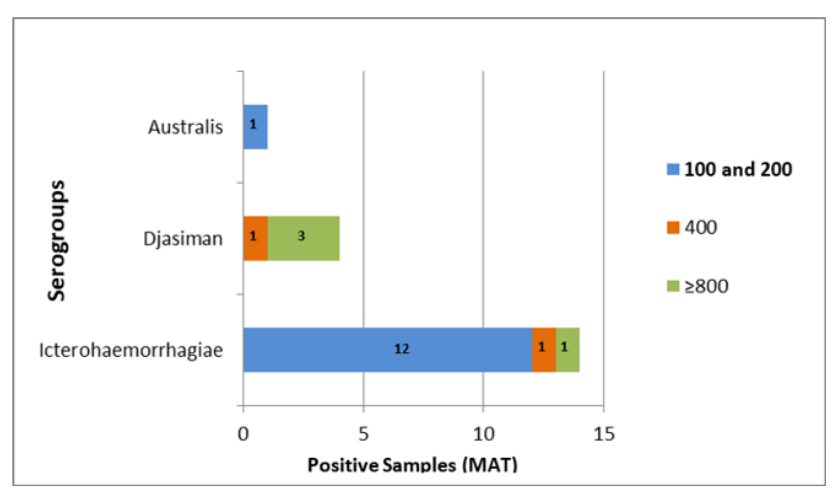

Figure 4. Titers of anti-Leptospira spp. antibodies in rodents of the Fernando de Noronha Island determined by MAT.

\section{DISCUSSION}

This is the most thorough study on Leptospira spp. infection in animals of an insular environment performed in Brazil. Differently from the study previously performed, in which only dogs of the Fernando de Noronha Island were evaluated [3], the present study included samples from all cattle raised in the Island, as well as feral cats and rodents.
In the present study, the occurrence of antiLeptospira spp. antibodies in cattle was $22.7 \%$, which is lower than that found in other studies conducted in continental Brazil and Latin America. Researchers screened cattle samples from 21 Brazilian states by MAT and found $37.94 \%$ seroreactivity, on average [15]. Studies performed in other Brazilian regions reported occurrence rates ranging from $30.3 \%$ in the state of São Paulo [24] to $81.9 \%$ in the state of Goiás [18]. According to researchers [32], in Latin America, the average occurrence of anti-Leptospira spp. antibodies in cattle is $44.2 \%$.

In our study, the cattle samples were only reactive against the serogroup Icterohaemorrhagiae (serovar Icterohaemorrhagiae). In contrast, most of the studies carried out in other countries reported the serogroup Serjoe as the most prevalent in cattle [2,9, $11,17,19,20,24,26,28,32,34,39]$. Cattle and sheep are maintenance hosts for the serovar Hardjo (serogroup Serjoe), which has a worldwide distribution, but has a low frequency in some areas of cattle breeding, especially in Scandinavian countries. The strains Hardjobovis and Harjoprajitno colonize and persist in the genital tract of infected cows and bulls, being responsible for venereal transmission and causing reproductive disorders in infected animals [13,42]. The absence of the serovar Hardjo in the cattle of the Fernando de Noronha Island is likely associated to no contact with cattle from the mainland where this serovar occurs.

Several other serovars including Icterohaemorrhagiae, Canicola, Hebdomadis, Sejroe, Pyrogenes, Autumnalis, Australis, Javanica, Tarassovi and Grippotyphosa have been associated with infection in cattle in other countries. Severe disease is usually uncommon and is associated to accidental infection by the serogroups Pomona, Icterohaemorrhagiae and Grippotyphosa, especially in young animals. Clinical signs include fever, hemolytic anemia, hemoglobinuria, jaundice, occasionally meningitis and death [13].

Researchers stated that despite the constant presence of the serovar Hardjo (serogroup Sejroe) in cattle, accidental infections by other serovars may occur as a result of indirect transmission by contact with leptospires shed by wild or domestic species [9]. The fact that $45 \%$ of the cattle reactive samples had an antibody titer greater than or equal to 400 (Figure 2) corroborates with the assumption that cattle are accidental hosts of the serogroup Icterohaemorrhagiae. 
This high serological response also demonstrates the poor adaptation of cattle to this serogroup [16,40].

Production animals were introduced in the Fernando de Noronha Island at the beginning of the last century. The cattle screened in the present study did not have contact with the animals from the mainland, being a population with peculiar genetic and management characteristics [31]. The predominance of the serogroup Icterohaemorrhagiae in the cattle herds of the Island is likely directly related to the infection in rodents, which were mainly infected by the same serogroup (Figure 4) and are known reservoirs of Icterohaemorrhagiae. Rodents may shed leptospires through their urine and contaminate water and feed, which could be a potential source of infection to cattle. From an epidemiological point of view, the predominance of the same Leptospira serovar in both cattle and rodents is an important finding because it shows the low diversity of Leptospira spp. serovars and serogroups in the insular environment unlike what happens in the mainland where probably there are several sources of infection and reservoirs to other serovars.

As a prophylaxis measure, we recommend the vaccination of the cattle herds of the Island with commercial vaccines containing the serovar Icterohaemorrhagiae, in order to reduce the impact of acute leptospirosis, especially in calves, and the risk of transmission to humans.

The frequency of anti-Leptospira spp. antibodies in rodents was $12.7 \%$, which is within the variation range found in other studies performed in Brazil: 0\% in the state of Minas Gerais [4] to $100 \%$ in the state of São Paulo [29]. Similarly to what was observed in cattle, the most prevalent serogroup in the rodents of the Fernando de Noronha Island was Icterohaemorrhagiae $(73.69 \%)$. Studies performed in continental Brazil also identified this serogroup as the most frequent in rodents $[14,10,21,22]$, confirming these animals as the main reservoirs of the serovar Icterohaemorrhagiae (serogroup Icterohaemorrhagiae) [13].

Besides the serogroup Icterohaemorrhagiae, $21.0 \%$ and $5.2 \%$ of the rodents also had antibodies against the serogroups Djasiman (serovar Djasiman) and Australis (serovar Bratislava), respectively. There is an extensive literature on leptospirosis in wild rodents; however, due to the large number of wild rodents and their distinct habitats, there is still a lack of information on rodents as carriers of leptospires and their clinical symptoms [13]. Most of the rodents reactive to the serovar Icterohaemorrhagiae (serogroup Icterohaemorrhagiae) (85\%) showed an antibody titer of up to 200 (Figure 4) demonstrating the adaptation of rodents to this serovar [16,40].

According to the Ministry of Health of Brazil [6], cases of human leptospirosis have been reported and confirmed in the Fernando de Noronha Island since 2005. According to the Epidemiological Surveillance Unit of the Island, the most prevalent serogroup in humans is Icterohaemorrhagiae demonstrating the importance of rodents in the dissemination and transmission of leptospires from this serogroup to humans in the Island.

The results found in the present study corroborates with the studies of researchers $[8,33,44]$ who have previously shown the importance of different animals in the epidemiological cycle of leptospirosis in oceanic islands.

None of the 200 feral cats was reactive against any of the 20 Leptospira spp. serovars tested. Similar results have been described by researchers in the state of Minas Gerais [33] and in the state of São Paulo, Brazil [25,36]. However, some researchers $[5,35]$ reported anti-Leptospira spp. antibodies in $5.43 \%$ and $22.6 \%$ of the surveyed cats in the states of Paraíba and Minas Gerais.

The entry and exit of companion animals such as cats in the Fernando de Noronha Island is controlled by the Epidemiological Surveillance of the Fernando de Noronha State District. However, the population of feral cats has grown wildly out of control over recent years, despite continuous control attempts, being a public health issue due to the zoonotic diseases carried by cats [23]. Although feral cats prey on rodents and $12.6 \%(19 / 150)$ of the rodent screened in the present study were positive for anti-Leptospira antibodies, none of the 200 feral cats evaluated were seropositive at the time of sampling, likely because cats are more resistant to leptospirosis than other animals [30]. Nevertheless, feral cats can not be ignored in the transmission cycle of leptospirosis, because at some point they may shed this bacterium in their urine and act as a source of infection to other animals and humans as already shown in experimental studies [38].

The Kernel estimate of the occurrence of seroreactivity of cattle and rodents to Leptospira spp. in the Fernando de Noronha Island showed that the 
infection foci are dispersed throughout the entire area where cattle are raised as well as at all rodent sampling sites. Therefore, better sanitary practices must be implemented in all cattle herds, as well as control of the rodent populations throughout the island.

\section{CONCLUSION}

This is the first report of occurrence of antiLeptospira spp. antibodies in cattle and rodents of the Fernando de Noronha Island, Brazil; Icterohaemorrhagiae was the most predominant serogroup in both group of animals. Considering the human cases of leptospirosis reported and confirmed in the Island, we believe that rodents and cattle play an important role in the dissemination of this disease. Therefore, strategies aimed at better sanitary management of the cattle herd as well as population control of rodents must be implemented in the Fernando de Noronha Island to secure a more sustainable animal production and to minimize the risks to public health.

\section{MANUFACTURERS}

${ }^{1}$ Vetnil-Indústria e Comércio de Produtos Veterinários Ltda. Louveira, SP, Brazil.

${ }^{2}$ Syntec-Tecnologia Farmacêutica Aplicada à Medicina Veterinária Ltda. Santana de Parnaíba, SP, Brazil.

Funding. This research did not receive any specific grant from funding agencies in the public, commercial, or not-for-profit sectors.

Ethical Approval. The study was approved by the Ethics Committee on the Use of Animals (Comitê de Ética no Uso de Animais - CEUA) of the Federal Rural University of Pernambuco (Universidade Federal Rural de Pernambuco - UFRPE) under the protocol number 138/2016. Permits for field collection were granted by the Chico Mendes Institute for Biodiversity Conservation (Instituto Chico Mendes de Conservação da Biodiversidade - ICMBio) through the System of Authorization and Information on Biodiversity (Sistema de Autorização e Informação em Biodiversidade - SISBIO) under the protocol number 56156.

Declaration of interest. The authors declared no potential conflicts of interest with respect to the research, authorship, and/or publication of this article.

\section{REFERENCES}

1 Adas M. \& Adas S. 1985. Panorama geográfico do Brasil: aspectos físicos, humanos e econômicos. 2nd edn. São Paulo: Moderna, 294p.

2 Aguiar D.M., Gennari S.M., Cavalcante G.T., Labruna M.B., Vasconcellos S.A., Rodrigues A.A.R., Moraes Z.M. \& Camargo L.M.A. 2006. Seroprevalence of Leptospira spp. in cattle from Monte Negro municipality, western Amazon. Pesquisa Veterinária Brasileira. 26(2): 102-104.

3 Andrade Filho G.V. 2012. Inquérito sorológico da leptospirose em cães da Região Metropolitana do Recife e da Ilha de Fernando de Noronha, PE. 51f. Recife, PE. Dissertação (Mestrado em Ciência Veterinária) - Programa de Pósgraduação em Ciência Veterinária, Universidade Federal Rural de Pernambuco.

4 Bevilacqua P.D., Carmo R.F., Silva J.C.P. \& Del Giudice G.M.L. 2004. Roedores inventariados em hospital veterinário e fragmento de mata nativa da Zona da Mata de Minas Gerais, Brasil: caracterização populacional e infecção por Leptospira sp. Ciência Rural, Santa Maria. 34(5): 1519-1523.

5 Brasil A.W.L., Parantoni R.M., Feitosa T.F., Vilela V.L.R., Alves C.J., Vasconcellos S.A. \& Azevedo S.S. 2014. Anticorpos anti-Leptospira spp. em gatos do semiárido do Estado da Paraíba. Ciências Agrárias. 35(6): 3215-3220.

6 Brasil. 2016. Ministério da Saúde. Sala de Apoio à Gestão Estratégica - SAGE,1p. Disponível em: <http://sage.saude. gov.br/\#>. [Accessed online in January 2017].

7 Brasil 2009. Secretaria de Vigilância em Saúde. Guia de vigilância epidemiológica, Secretaria de Vigilância em Saúde. 6nd edn. Brasília: Ministério da Saúde, 816p.

8 Buchholz A.E., Katz A.R., Galloway R., Stoddard R.A. \& Goldstein S.M. 2016. Feral Swine Leptospira Seroprevalence Survey in Hawaii, USA, 2007-2009. Zoonoses and Public Health. 63(8): 584-587.

9 Castro V., Azevedo S.S., Gotti T.B., Batista C.S.A., Gentili J., Moraes Z.M., Souza G.O., Vasconcellos S.A. \& Genovez M.E. 2008. Soroprevalência da leptospirose em fêmeas bovinas em idade reprodutiva no estado de São Paulo, Brasil. Arquivo Instituto Biológico, São Paulo. 75(1): 3-11.

10 Corrêa S.H.R., Vasconcellos S.A., Morais Z., Teixeira A.A., Dias R.A., Guimarães M.A.B.V., Ferreira F. \& Ferreira Neto J.S. 2004. Epidemiologia da Leptospirose em animais silvestres na Fundação Parque Zoológico de São Paulo. Brazilian Journal of Veterinary Research and Animal Science. 41(3): 189-193. 
11 Del Fava C., Vasconcelos S.A., D'angelo J.L., Morais Z.M., Figueiredo L.A., Razook A.G., Cyrillo J.N.S.G., Oliveira J.V. \& Reichert R.H. 2004. Coeficientes reprodutivos e soropositividade para Leptospira spp. em rebanho bovino de corte no estado de São Paulo, Brasil. Ars Veterinaria. 20(1): 52-61.

12 Durski K.N., Jancloes M., Chowdhary T. \& Bertherat E. 2014. A global, multi-disciplinary, multi-sectorial initiative to combat Leptospirosis: Global Leptospirosis Environmental Action Network (GLEAN). Internnational Journal Environmental Reseach and Public Health. 11(6): 6000-6008.

13 Ellis W.A. 2015. Animal Leptospirosis. In: Adler B. (Ed). Leptospira and Leptospirosis of the series Current Topics in Microbiology and Immunology. 387.ed. Berlin: Springer, pp.99-137.

14 Esteves F.M., Guerra-Neto G., Girio R.J.S., Silva-Vergara A.C. \& Carvalho A.C.F.B. 2005. Detecção de anticorpos para Leptospira spp. em animais e funcionários do zoológico municipal de Uberaba, MG. Arquivo do Instituto Biológico, São Paulo. 72(3): 283-288.

15 Favero M., Pinheiro S.R., Vasconcellos S.A., Morais Z.M. \& Ferreira F., Ferreira-Neto J.S. 2001. Leptospirose bovina: variantes sorológicas predominantes em colheitas efetuadas no período de 1984 a 1997 em rebanhos de 21 estados do Brasil. Arquivo do Instituto Biológico, São Paulo. 68(2): 29-35.

16 Gomes M.J.P. 2013. FAVET-UFRGS. Gênero Leptospira spp., 52p. Disponível em: <https://edisciplinas.usp.br/ pluginfile.php/393176/mod_folder/content/0/G\%C3\%AAnero\%20Leptospira\%20\%202015.pdf?forcedownload=1>. [Accessed online in January 2017].

17 Hamond C., Martins G., Lilenbaum W., Pinna M. \& Medeiros M.A. 2015. Infection by Leptospira spp. in Cattle in a Tropical Region, Rio de Janeiro, Brazil. American Journal of Tropical Medicine and Hygiene. 92(1): 210.

18 Juliano R.S., Chaves N.S.T., Santos C.A., Ramos L.S., Santos H.Q., Meireles L.R., Gottschalk S. \& Corrêa Filho R.A.C. 2000. Prevalência e aspectos epidemiológicos da Leptospirose bovina em rebanho leiteiro na Microrregião de Goiânia - GO. Ciência Rural. 30(5): 857-862.

19 Lage A.P., Leite R.M.H., Thompson J.A., Bandeira D.A., Herrman G.P., Moreira E.C. \& Gonçalves V.S.P. 2007. Serology for Leptospira sp. in cattle of the State of Paraíba, Brazil. Arquivo do Instituto Biológico. 74(3): 185-190.

20 Langoni H., Meireles L.R., Gottschalk S., Cabral K.G. \& Silva A.V. 2000. Perfil sorológico da leptospirose bovina em regiões do Estado de São Paulo. Arquivo do Instituto Biológico. 67(1): 37-41.

21 Leal N.C. 1986. Leptospirose em ratos na Cidade do Recife, Pernambuco, Brasil. Revista de Microbiologia. 17(3): 216-219.

22 Lilenbaum W., Ribeiro V., Martin E. \& Bispo V. 1993. Serological studies on antileptospira antibodies in Rattus norvegicus from Duque de Caxias, Rio de Janeiro, Brazil. Revista Latinoamericana de Microbiologia. 35: 357-360.

23 Magalhães F.J.R. 2016. Infecção por Toxoplasma gondii em animais na Ilha de Fernando de Noronha, Brasil: prevalência, distribuição espacial e fatores de risco. 70f. Recife, PE. Tese (Doutorado em Ciência Animal Tropical) - Programa de Pós-graduação em Ciência Animal Tropical, Universidade Federal Rural de Pernambuco.

24 Martins L.S. 2005. Situação epidemiológica da leptospirose bovina, canina e humana na área rural do município de Pirassununga, SP. 80f. São Paulo, SP. Tese (Doutorado em Medicina Veterinária) - Programa de Pós-graduação em Epidemiologia Experimental e Aplicada às Zoonoses, Universidade de São Paulo.

25 Mittestainer J.C., Melchert A., Ribeiro J.F.A., Sartori R.S., Joaquim S.F., Bresciani K. \& Langoni H. 2015. Estudo soroepidemiológico da infecção por Leptospira spp. em gatos. Arquivo Brasileiro Medicina Veterinária Zootecnia. 22(3): 465-470.

26 Oliveira A.A., Mota R.A., Pereira G.C., Langoni H., Souza M.I., Navagantes W.A. \& Sá M.E. 2001. Seroprevalence of bovine leptospirosis in Garanhuns Municipal District, Pernambuco State, Brazil. Onderstepoort Journal of Veterinary Research. 68(4): 275-279.

27 Oliveira D.S.C., Guimarães M.J.B. \& Medeiros Z. 2009. Modelo produtivo para a leptospirose. Revista de Patologia Tropical. 38(1): 17-26.

28 Oliveira F.C.S., Azevedo S.S., Pinheiro S.R., Viegas S.A.R.A., Batista C.S.A., Coelho C.P., Moraes Z.M., Souza G.O., Gonçalves A.P., Almeida C.A.S. \& Vasconcellos S.A. 2009. Soroprevalência de leptospirose em fêmeas bovinas em idade reprodutiva no Estado da Bahia. Arquivo do Instituto Biológico, São Paulo. 76(4): 539-546.

29 Paixão M.S., Alves-Martin M.F., Tenório M.S., Starke-Buzetti W.A., Alves M.L., Da Silva D.T., Ferreira A.G., Floró e Silva M., Sousa L.O. \& Lucheis S.B. 2014. Serology, isolation, and molecular detection of Leptospira spp. from the tissues and blood of rats captured in a wild animal preservation centre in Brazil. Preventive Veterinary Medicine. 115(1-2): 69-73. 
30 Parreira I.M. 2009. Aspectos epidemiológicas da infecção por Leptospira spp. em felinos domésticos (Felis catus) aparentemente sadios da região metropolitana de Goiânia, Goiás. 70f. Dissertação (Mestrado em Ciência Animal) Programa de Pós-graduação em Ciência Animal, Universidade Federal de Goiás, Goiânia.

31 Pernambuco. 2015. Noronha PE. Fauna do Arquipélago de Fernando de Noronha, 1p. Disponível em: <http://www. noronha.pe.gov.br $>$. [Accessed online in November 2015].

32 Pinto P.S., Libonati H., Penna B. \& Lilenbaum W. 2016. A systematic review on the microscopic agglutination test seroepidemiology of bovine leptospirosis in Latin America. Tropical Animal Health and Production. 48(2): 239-248.

33 Plata-Luis J., Foronda P., Martín-Alonso A., Feliu C., Alves J., Gil H. \& Valladares B. 2016. Leptospira interrogans in Rodents from Cape Verde. Vector Borne and Zoonotic Diseases. 16(11): 731-733.

34 Rende J.C. \& Ávila S.A. 2003. Leptospirose bovina: perfil epidemiológico e dinâmica de infecção como zoonose. Ars Veterinaria. 19(1): 71-79.

35 Santos J.P., Ferreira Júnior A., Mundim E.V., Santos M.P., Oliveira P.R. \& Lima A.M.C. 2006. Pesquisa de aglutininas anti-Leptospira em gatos errantes da cidade de Uberlândia - MG. Veterinária Notícias. 12(2): 122.

36 Sarmento A.M.C., Guazelli A., Barreto L.F.G., Costa V.M., Hoffmann J.L., Lucheis S.B., Langoni H. \& Pinheiro S.R. 2007. Estudo da leptospirose em cães e gatos, da leishmaniose e da doença de chagas em cães de aldeias indígenas guaranis em Parelheiros, município de São Paulo - SP. Arquivo Brasileiro Medicina Veterinária Zootecnia. 14(2): 193203.

37 Sehgal S.C. 2006. Epidemiological patterns of leptospirosis. Indian Journal of Medical Microbilog. 24(4): 310-311.

38 Shophet R. \& Marshall R.B. 1980. An experimentally induced predator chain transmission of Leptospira ballum from mice to cats. British Veterinary Journal. 136(3): 265-270.

39 Silva F.J., Conceição W.L.F., Fagliari J.J., Girio R.J.S., Dias R.A., Borba M.R. \& Mathias L.A. 2012. Prevalência e fatores de risco de leptospirose bovina no Estado do Maranhão. Pesquisa Veterinária Brasileira. 32( 4): 303-312.

40 Tagliabue S., Figarolli B.M., D’incau M., Foschi G., Gennero M.S., Giordani R., Natale A., Papa P., Ponti N., Scaltrito D., Spadari L., Vesco G. \& Ruocco L. 2016. Serological surveillance of Leptospirosis in Italy: two year national data (2010 2011). Veterinaria Italiana. 52(2): 129-138.

41 Teixeira W., Cordani U.G., Menor E.A., Teixeira M.G. \& Linsker R. 2003. Arquipélago de Fernando de Noronha o paraíso do vulcão. São Paulo: Terra Virgem, 168p.

42 Varges R.G. 2009. Correção de fatores de manejo como ferramenta complementar ao controle de leptospirose em um rebanho bovino no estado do Rio de Janeiro, Brasil. 92f. Niterói, RJ. Tese (Doutorado em Medicina Veterinária) - Pósgraduação em Medicina Veterinária, Universidade Federal Fluminense.

43 World Health Organization. 2003. Human leptospirosis: guidance for diagnosis, surveillance and control. Geneva: World Health Organization, 122p. Disponível em: <http://www.who.int/iris/handle/10665/42667>. [Accessed online in January 2017].

44 Wong M., Katz A.R., Li D. \& Wilcox B.A. 2012. Leptospira Infection Prevalence in Small Mammal Host Populations on Three Hawaiian Islands. American Journal Tropical Medicine Hygiene. 87(2): 337-341. 